\title{
PROBABILITY OF DEFAULT MEASUREMENT MODELS OF MERTON ON SHARIAH BANKS AND CONVENTIONAL BANKS IN INDONESIA FOR 2011-2017 PERIOD
}

\author{
Okta Silvira ${ }^{1}$ \\ Lina Nugraha Rani ${ }^{2}$
}

\begin{abstract}
This paper provides empirical evidence of the comparison default risk in Islamic banks and conventional banks in Indonesia over the 2011 to 2017 period. The calculation of bank default risk using a Merton Model has allowed the measure of the Distanceto-Default (DD) and Default probability (DP). This study was extended to investigate the differences of bank default risk between Islamic banks and conventional banks with the employ of T-test. The evidence shows Islamic banks as banks that are far from the Possibility of Default Risk rather than conventional banks. The T-test indicates that there are significant differences in the Probability of Default values between Islamic banks and conventional banks. These findings could be relevance to regulators in Indonesia to support the growth of Islamic, which helps in maintaining financial system stability and avoiding systemic risk.
\end{abstract}

Keywords: Islamic banks, conventional banks, default risk, Merton's model, systemic risk

\footnotetext{
1 Student, Islamic Economics, Faculty of Economics and Business, Universitas Airlangga, Indonesia, oktasilvira10@gmail.com

2 Lecturer, Islamic Economics, Faculty of Economics and Business, Universitas Airlangga, Indonesia, linanugraha@feb.unair.ac.id
} 


\section{INTRODUCTION}

Banking is one of the important sectors that can maintain the financial and economic stability of a country. In Indonesia, the current rate of banking growth is increasing tremendously. This was seen since the Government Law No. 10 of 1998 replacing Government Law No. 7 of 1992, which was recognized through the existence of two banking systems (dual banking system), namely conventional banking and Islamic banking. Islamic Bank is a bank that runs its business activities based on the principle of profit-sharing. Unlike Islamic banks, conventional banks are banks that carry out their business activities conventionally and adhere to the bank interest system (usury) in the type of compensation. The latter activity is very contrary to Islam, as the principle of bank interest (usury) is strictly prohibited and haräm by the law.

As an intermediary, both conventional banks and Islamic banks have the duty to collect funds from the public in the form of deposits and redistribute them to the community in the form of credit or financing. In this case, the bank is required to be able to provide a number of funds that are ready to be used or can be withdrawn at any time by the customer. If the bank is unable to provide sufficient funds, then it can be ascertained that the bank is experiencing financial problems.

The importance role of risk management at Islamic banks and conventional banks must be highly risk-emphasized in order to improve its performance and profitability on a sustainable. Risks faced by banks include operational risks, market risks, and credit risks. Banking performance is also exposed by an environment that continues to challenge banking capabilities that could increase shareholders' value through a balanced risk-return profile. This is based on the experience of the collapse of the financial sector at the time of the subprime mortgage crisis. ${ }^{3}$

The operation of Islamic banks in the issuance of product contracts is the same as conventional banks, which it will be closely related to market risks and credit risks, as well as other risks involving strategy, liquidity, and operations. Islamic bank term deposit products are changed in the form of Profit-sharing investment accounts (PSIAs) based on reverse muräbahah transactions. Islamic banks that were established earlier than conventional banks face challenges in liquidity management as well as reliance on deposits. Therefore, Islamic banks must conduct liquidity risk management by maintaining higher

\footnotetext{
3 Masood, O., Tafri, F. H., Rahman, R. A. \& Omar, N., 'Empirical Evidence on the Risk Management Tools Practised in Islamic and Conventional Banks,' Qualitative Research in Financial Markets, vol. 3 (2011): 86-104.
} 
liquidity buffers, for example through $s u k \bar{u} k$ so that Islamic banks could avoid competition in the same market as conventional banks. Raising deposits in the form of term deposits at Islamic banks and conventional banks continuously can be a source of systemic risk. ${ }^{4}$

Systemic risks and default risk are the risks that possibly occur in a bank. Systemic risk can be expressed as a risk that causes failure of one or several financial institutions as a result of systemic events. ${ }^{5}$ Meanwhile, the risk of failure (default risk) is the uncertainty of banks' ability to pay debts and obligations. ${ }^{6}$

One of the greatest challenges that financial institutions in general and banks in particular face is coping with increasing uncertainties and accompanying risks. This has become particularly crucial in the context of the current financial turmoil, which has highlighted a miss-assessment of risk on behalf of banks, investors, as well as supervisors, with overwhelming and far reaching implications for financial stability. ${ }^{7}$

So as to prevent the risk threat, an early warning system that can provide anticipatory action has become a necessity. The purpose of the early warning system is to measure the risk of supervision and identify problems in the banking financial system. The measurement used as an early warning system in this study is Probability of Default (PD). According to Hadad et al., ${ }^{8}$ the definition of Probability of Default is a form of valuation that uses the Merton model in order to see a company based on market valuation using specific assumptions related to the condition of the company's assets and liabilities.

4 Hasan, M. \& Dridi, J., 'The Effects of the Global Crisis on Islamic and Conventional Banks: A Comparative Study,' Journal of International Commerce, Economics and Policy, vol. 2/2 (2011): 163-200.

5 Ayomi, Sri \& Bambang Hermanto, 'Mengukur Risiko Sistemik dan Keterkaitan Finansial Perbankan di Indonesia,' Buletin Ekonomi Moneter dan Perbankan, vol. 16/2 (2013): 103-125.

6 Ayomi, Sri \& Bambang Hermanto, 'Mengukur Risiko Sistemik dan Keterkaitan Finansial Perbankan di Indonesia,' 103-125.

7 Koutsomanoli-Filippaki, A. \& Mamatzakis, E., 'Performance and Merton-type Default Risk of Listed Banks in the EU: A Panel VAR Approach,' Journal of Banking \& Finance, vol. 33/11 (2009): 2050-2061.

8 Hadad et al., Probabilitas Kegagalan Korporasi dengan Menggunakan Model Merton (Jakarta: Direktorat Penelitian dan Pengaturan Perbankan (BSSK-DPNP) Bank Indonesia, 2004). 
The Probability of Default measurement in this study uses the Merton model. According to Merton, ${ }^{9}$ the Merton model has the advantage of a stronger theoretical framework compared to other default prediction models. This is because other bankruptcy prediction models such as the Altmans Z-score model ${ }^{10}$ with discriminant analysis and Ohson model (1980) with logit models are considered to have no strong theoretical financial basis compared to Merton's structural model. ${ }^{11}$

DD (Distance Default) is the number of standard deviations that the bank's asset value must fall in order to reach the default point. A higher DD score then indicates the value of the firm as far from the default point, thus lowering the probability of default. For example, if a bank's expected market value of its assets in one year is 100 and the default point is 20 , then an 80 percent drop in the market value of assets would make the bank default. The probability of the market value of assets falling from 100 to 20 depends on the volatility of the bank's asset value. For example, if the volatility of the bank's asset value is 10 percent, then 8 standard deviation points would be needed in order to reach a default point of $20 .^{12}$

Theoretically, if DD is zero for a particular bank at a particular time, the bank should already be in default position. However, if a bank can continue to rollover its short-term liabilities, it may survive on a cash flow basis eventhough the bank is technically insolvent. All other things being equal, where the closer the default point to zero, the more vulnerable the position of the bank, whereas the higher the default point, the lower the probability of default of a particular bank. ${ }^{13}$

The paper aims to analyze the systemic risks present in Islamic banks and conventional banks, where both types of banks are operating in the same market share in Indonesia, and addresses three broad questions, namely (i)

9 Merton, Robert C., On the Pricing of Corporate Debt: The Risk Structure on Interest Rates (New York: Wiley and American Finance Association, 1974).

10 Altman, E., 'Financial Ratios, Discriminant Analysis and the Prediction of Corporate Bankruptcy,' The Journal of Finance, vol. 23. No. 4 (1968): 589-609.

11 Wibowo, Buddi, 'Metode Pengukuran Probabilitas Kebangkrutan Bank dan Analisis Hubungannya dengan Diversifikasi Sumber Pendapatan: Kasus Perbankan Indonesia,' Matrik: Jurnal Manajemen Strategi Bisnis dan Kewirausahaan, vol. 11/1 (2017): 52-66.

12 Kabir, Nurul, 'Comparative Credit Risk in Islamic and Conventional Bank,' Pacific-Basin Finance Journal, vol. 34 (2015): 327-353.

13 Bharath, S. T. \& Shumway, T., 'Forecasting Default with the Merton Distance to Default Model,' The Review of Financial Studies, vol. 21/3 (2008): 1339-1369. 
is the systemic risk to Islamic banks greater than conventional banks? (ii) is there a high enough difference between the systemic risk of Islamic banks and conventional banks?, and (iii) what causes the systemic risks of Islamic banks to differ from conventional banks? In this study, systemic risk was measured by assessing Distance Default (DD) and Probability Default (PD) in banking.

\section{LITERATURE REVIEW}

According to Machmud and Rukmana ${ }^{14}$ conventional banks and Islamic banks have major differences. The main differences between conventional banks and Islamic banks can be seen from the following four aspects:

a) Philosophy: Islamic banks are not based on interest, speculation and obscurity, while conventional banks are based on interest.

b) Operations: In Islamic banks, public funds in the form of deposits and new investments will get results if been cultivated first, while in conventional banks, public funds in the form of deposits must be paid interest at maturity. On the distribution side, Islamic banks channel their funds to business sectors that are lawful and profitable, while for those in conventional banks, this matter is not their main consideration.

c) Social: In Islamic banks, social aspects are explicitly and explicitly stated in the company's vision and mission, while conventional banks are not explicitly implied.

d) Organizations: Shariah banks must have and be supervised by Shariah Supervisory Board (SSB). Meanwhile, conventional banks do not have any.

According to Karim $^{15}$ regarding an intermediary institution, banks will always be faced with various types of risks inherent in each of their business activities. Risk in banking is a potential event, both anticipated and unanticipated. Risks can have a negative impact on the income and capital of banking institutions. Various risks in the banking sector cannot be avoided. However, it can be managed and controlled so as not to adversely affect their business activities. Therefore, both Islamic banks and conventional banks require a series of procedures that can be used to identify, monitor, and control the running of bank business activities with a reasonable, directed, integrated

14 Machmud, Amir \& Rukmana, Bank Syariah Teori, Kebijakan, dan Studi Empiris di Indonesia (Jakarta: PT. Gelora Aksara Pratama, 2010), 11.

15 Karim, Adiwarman, Bank Islam Analisis Fiqih dan Keuangan (Jakarta: PT. Raja Grafindo Persada, 2014), 255. 
and sustainable level of risk. The function of risk management is to act as a filter or an early warning system for all bank business activities.

According to Wiranatakusuma and Duasa, ${ }^{16}$ an Early Warning System or commonly called an early warning system is a system used to build early warnings for banking resilience in Indonesia. This early detection system is widely used as a monitoring mechanism that is useful for maintaining financial system stability. The development of the early warning system has long been a major interest for central banks and academics, by being an effort to prevent the shock of the banking crisis in Indonesia, which has resulted in an influential economic downturn on banking institutions.

The most classic Probability of Default study is Merton. ${ }^{17}$ This study attempts to calculate the risk of corporate failure based on the Black-Scholes ${ }^{18}$ option pricing formula to measure the distance of default (default to default) and the possibility of default. Merton states that the failure of a company can be estimated using indicators of total assets, equity, and corporate debt. Merton's opinion is more in stating that the equity and debt of a company are call option on the value of the company's assets. Another Merton assumption assumes that the company that has a zero-coupon bond amount must be repaid in the future (time $\mathrm{t}$ ). The purpose of this assumption is to ensure that the company will be considered the default if the value of the assets it has is smaller than the value of the debt that will be repaid at the t-time. The analytical method used to measure the Probability of Default Islamic Banks and Conventional Banks in this study is the Merton structural model. The Merton model is a development model of the Black-Scholes Model. The Merton model states that corporate failure can be estimated using indicators of total assets, equity, and company debt (liabilities).

Jessen and Lando ${ }^{19}$ said that the good ranking performance of a measure based on the Merton model is striking in view of the model's somewhat poorer ability to capture the level of default probabilities and in view of its simple assumptions on asset dynamics and debt structure. In this paper, we investigate whether the success of the distance-to-default can in part be explained by a

16 Wiranatakusuma, D. B. \& Duasa, J., 'Building An Early Warning Towards the Resilience of Islamic Banking in Indonesia,' Al-Iqtishad: Jurnal Ilmu Ekonomi Syariah, vol. 9/1 (2017): 13-32.

17 Merton, Robert C., On the Pricing of Corporate Debt: The Risk Structure on Interest Rates.

18 Black, F., Scholes, M., 'The Pricing of Options and Corporate Liabilities,' The Journal of Political Economy (1973): 637-654.

19 Jessen, C. \& Lando, D., 'Robustness of Distance-to-Default,' Journal of Banking \& Finance, vol. 50 (2015): 493-505. 
strong robustness to model misspecifications. In other words, is it the case that the distance-to-default measure performs well even if the observed data are generated using other asset value dynamics or different default triggering mechanisms? As part of this agenda, we focus on understanding which deviations from the underlying Merton model that may cause the distance-todefault to fail in its ranking of firms. We base all of our results on simulated samples to allow the tightly controlled experiments. We find that changing the default triggering. The result of DD has proven empirically to be a strong predictor of default. We use simulations to show that the empirical success of DD may well be a result of its strong robustness to model misspecifications. We consider a number of deviations from the Merton model which involve different asset value dynamics and different default triggering mechanisms. Generally, DD is successful in ranking firms' default probabilities, even if the underlying model assumptions are altered. A possibility of large jump in asset value or stochastic volatility could challenge the robustness of DD.

Kabir et al. research ${ }^{20}$ measured credit risk based on Merton's distanceto-default (DD) model at 21 banks with details of 156 conventional banks and 37 Islamic banks, and compared the results of DD measurements with Z-Score and Non Performing loans (NPLs). The results of this study show the credit risk in Islamic banks as lower than conventional banks. However, the measurement results using Z-Score and NPL suggest that the risk of Islamic bank credit is higher than that of conventional banks.

According to Boumediene, ${ }^{21}$ credit risk is the main risk that can cause bank default, so it is important to measure the level of credit risk. In this study, the data of 9 conventional banks and Islamic banks for the period 2005-2019 is utilized in order to measure the level of credit risk using Distance-toDefault (DD) and Probability Default (DP) with the Merton Model (1974). The measurement results show that the DD of Islamic banks is higher than conventional banks while the Default Probability (DP) of conventional banks is higher than Islamic banks. These results indicate that conventional banks have a higher credit risk than conventional banks.

20 Kabir, Nurul, 'Comparative Credit Risk in Islamic and Conventional Bank,' 327353.

21 Boumediene, A., 'Is Credit Risk Really Higher in Islamic Banks?' SSRN Electronic Journal, vol. 7/3 (2010): 1-36. 


\section{HYPOTHESIS}

T-test is applied to measure the difference in default risk between Islamic banks and conventional banks. Saeed and Izzeldin ${ }^{22}$ stated that Islamic banks and conventional banks have the same role and function as financial intermediation institutions. Conventional banks have their different concepts that are very different from Islamic banksincluding on the interest rates as a basis for getting profit in carrying out their duties as an intermediary between depositors and borrowers. Islamic Bank-based operations are based on contracts that avoid interest rates with the concept of profit-loss sharing between the capital provider and the entrepreneur. The difference in the basic operational concept of Islamic banks with conventional banks will also affect the default risk of both types of banks.

\section{Hypothesis 1: There is a significant difference in default risk between Islamic banks and conventional banks}

\section{METHODOLOGY}

\section{Type of Research Approach}

This study uses a quantitative approach because it uses data that can be measured in a way to determine the comparison of research samples based on the hypothesis set in the previous chapter. The purpose of this study is to compare the level of Probability of Default in each Islamic banks and conventional banks in Indonesia in the period 2011-2017. The Merton model is used by this research to calculate the Probability of Default value in Islamic banks and conventional banks in Indonesia. Furthermore, the data analysis techniques used in this study were descriptive statistical analysis, normality test, and two different samples. This study uses two different independent sample tests on Islamic commercial bank and conventional commercial banks, as both banks are two samples that are different and not interconnected.

22 Saeed, M., \& Izzeldin, M., 'Examining the Relationship between Default Risk and Efficiency in Islamic and Conventional Banks,' Journal of Economic Behavior \& Organization, vol. 132 (2016): 127-154. 


\section{Population and Samples}

The populations in this study are Islamic Banks and conventional Banks which are still actively operating in Indonesia to date. In this study, the sampling technique used was purposive sampling technique, which helps in detemining whether the Islamic Banks are registered at Financial Services Authority and was established in 2011. This is because 2011 is the year that used as the time period in this study. The first conventional bank data sample that searched from the parent bank of the Islamic bank before the spin-off and the rest of the bank was sought from banks with the same book category as Islamic banks. In addition, the number of 11 banks to be sorted into comparisons of Islamic banks with conventional banks that became Parent banks before spin-off and conventional banks are posited under the same category of business activities called the Commercial Banks Based on Business Activities which see bank capital as a reference. The category is based on Indonesia Government Regulation at Financial Advidory Board Number: 6/POJK.3/2016. This study uses a sample of 11 Shariah commercial banks and 11 conventional commercial banks to compare the Probability of Default, and the details are explained in Table 1:

Table 1: Sample of Islamic Banks (IBs) and Conventional Banks (CBs)

\begin{tabular}{ccc}
\hline No. & Islamic Bank (IB) & Conventional Bank (CB) \\
\hline 1. & IB1 & CB1 \\
2. & IB2 & CB2 \\
3. & IB3 & CB3 \\
4. & IB4 & CB4 \\
5. & IB5 & CB5 \\
6. & IB6 & CB6 \\
7. & IB7 & CB7 \\
8. & IB8 & CB8 \\
9. & IB9 & CB9 \\
10. & IB10 & CB10 \\
11. & IB11 & CB11 \\
\hline
\end{tabular}

Source: Otoritas Jasa Keuangan, Statistik Perbankan Indonesia 2017 and Statistik Perbankan Syariah (Jakarta: Otoritas Jasa Keuangan, 2017). 


\section{Data Analysis Technique}

\section{a) Descriptive Statistics}

In this study, we will describe the Probability of Default values of each Probability of Default in Islamic Banks and Conventional Banks. The calculation of the probability of default used in this study is shown as follows:

According to Sri Ayomi and Bambang Hermanto, ${ }^{23}$ calculating returns from the total assets of each bank can be formulated as follows:

$$
X_{t}=\frac{A_{t}-A_{t-1}}{A_{t-1}}
$$

Where, $\quad \mathrm{X}_{\mathrm{t}} \quad=$ Total asset return of the entire banking system

$\mathrm{A}_{\mathrm{t}} \quad=$ total banking assets in year $\mathrm{t}$

$\mathrm{A}_{\mathrm{t}-1}=$ total banking assets in the previous year

According to Anang Asdriargo et al., ${ }^{24}$ calculating the standard deviation $(\sigma)$ of the return on the total assets of each bank can be written as follows:

Where, $\quad \sigma=$ Standard deviation

$$
\sigma=\sqrt{\frac{\sum_{t=1}^{n}\left(x_{i}-\bar{x}\right)^{2}}{n-1}} .
$$

$n \quad=$ Amount of data

$x_{i} \quad=$ Data $\mathrm{i}(\mathrm{i}=1,2,3, \ldots \mathrm{N})$

$\bar{x} \quad=$ Sample average

According to Kabir et al., ${ }^{25}$ calculating Distance to Default (DD) of each bank can be formulated as follows:

$$
\mathbf{D D}=\frac{\ln \frac{v_{A}}{x_{\mathrm{t}}}+\left(\mu-\frac{1}{2} \sigma^{2}\right) \mathrm{T}}{\sigma \sqrt{T}}
$$

23 Ayomi, Sri \& Bambang Hermanto, Mengukur Risiko Sistemik dan Keterkaitan Finansial Perbankan di Indonesia.

24 Anang Asdriargo et al., 'Pengukuran Risiko Kredit Harga Obligasi Dengan Pendekatan Model Struktural Kmv Merton,' Jurnal Gaussian, 1/1 (2012): 11-20.

25 Kabir et al., 'Comparative Credit Risk in Islamic and Conventional Bank,' 327353. 
According to Maria Larsosson and Anna Magne, ${ }^{26} \mu$ can be assumed to be $r$. So that the Distance to Default (DD) formula is formulated as follows:

$$
\mathbf{D D}=\frac{\ln \frac{v_{e}}{x_{\mathrm{t}}}+\left(r-\frac{1}{2} \sigma^{2}\right) \mathrm{T}}{\sigma \sqrt{T}}
$$

Where,

$$
\begin{aligned}
& \mathrm{DD}=\text { Distance to Default } \\
& V_{A}=\text { total assets } \\
& r=\text { risk-free interest rates using the BI-rate } \\
& \sigma=\text { standard deviation of returns from total assets calculated in the previous stage } \\
& \mathrm{T}=\text { assumed period of } 1 \text { year }
\end{aligned}
$$

According to Nurul Kabir et al., ${ }^{27}$ calculating Probability of Default (PD) is formulated as follows:

Where,

$$
\begin{aligned}
& \mathrm{PD}=\text { Probability of Default } \\
& \mathrm{N}=\text { cumulative normal distribution }
\end{aligned}
$$

\section{b) Normality Test}

The normality test in this study uses the Shapiro-Francia normality test, and this is parallel to this study that uses a sample of between 3 and 2,000. The ShapiroFrancia test is carried out using the help of a computer program statistical analysis called Stata 14.2. If the result of the calculation of a significant value is greater than 0.05 (P 5 0.05), then the data is said to be normally distributed. Conversely, if the results of the calculation of a significant value are smaller than 0.05 (P 5 0.05), then the data is said to be not normally distributed.

\section{c) Two Independent Samples Different Tests}

Different test of two independent samples have two approaches, namely parametric with independent sample T-test and non-parametric with median test, Wlicoxon-Mann-Whitney test or Kolmogrov-Smirnov Two Sample Test. Different test of two independent samples in this study are using a computer program for statistical analysis named Stata 14.2. According to the characteristics of the Independent test, this sample t-test is carried out when the data is normally distributed. Meanwhile, the Mann Whitney $U$ test is done when the data is not normally distributed.

\footnotetext{
26 Larsson, Maria \& Birger Nilsson, 'Predicting the Default Probability of Companies in USA and EU During the Financial Crisis: A Study Based on the KMVTM Model,' (Master Thesis, Lund University, Swedia, 2010).

27 Nurul Kabir et al., 'Comparative Credit Risk in Islamic and Conventional Bank,' 327-353.
} 


\section{RESULTS AND ANALYSIS}

Calculation of the Probability of Default Merton model is done to determine the magnitude of the Probability of Default value in each Islamic banks and conventional banks (Appendix 1.). Based on Table 2 and Table 3 above, it can be concluded that each Islamic banks and conventional banks have a Probability of Default value which is very much the difference. According to Kabir et al. (2014), the value of Distance to Default (DD) has an influence on the level of Probability of Default (PD) in each company. The higher the Distance to Default (DD) value, the lower the Probability of Default (PD) level. A higher DD value indicates that the value of the banking company is far from the default risk point, which decreases the probability of default. The highest and lowest average Probability of Default in Islamic banks and conventional banks can be seen briefly in Table 2 :

Table 2: Average highest and lowest Probability of Default (PD) on Islamic banks and conventional banks

\begin{tabular}{|c|c|c|c|}
\hline $\begin{array}{c}\text { Bank } \\
\text { Category } \\
\end{array}$ & Bank name & Average PD & Information \\
\hline \multirow{7}{*}{ Islamic Banks } & 1. IB4 & 1.1419E-91 & \multirow{3}{*}{ Lowest Islamic bank } \\
\hline & 2. IB6 & $1.68 \mathrm{E}-32$ & \\
\hline & 3. IB1 & $1.4309 \mathrm{E}-17$ & \\
\hline & & & \\
\hline & 1. IB10 & 0.38005843 & \multirow{3}{*}{ Highest Islamic bank } \\
\hline & 2. IB11 & 0.22451799 & \\
\hline & 3. IB3 & 0.1639196 & \\
\hline \multirow{6}{*}{$\begin{array}{l}\text { Conventional } \\
\text { Banks }\end{array}$} & 1. $\mathrm{CB} 1$ & $1.7822 \mathrm{E}-05$ & \multirow{3}{*}{ Lowest Conventional bank } \\
\hline & 2. $\mathrm{CB} 7$ & $3.1817 \mathrm{E}-05$ & \\
\hline & 3. $\mathrm{CB} 3$ & 0.00011895 & \\
\hline & 1. $\mathrm{CB} 5$ & 0.21773164 & \multirow{3}{*}{ Highest Conventional bank } \\
\hline & 2. $\mathrm{CB} 6$ & 0.17186006 & \\
\hline & 3. $\mathrm{CB} 11$ & 0.0554459 & \\
\hline
\end{tabular}

Source: Results of author data processing, 2019 
Based on Table 2, it can be seen that there are 3 Islamic banks that have the highest and lowest Probability of Default, and 3 conventional banks that have the highest and lowest Probability of Default. For BUS with the lowest average Probability of Default, IB4 stands with an average of PD value at 1.1419E-91. Second, IB6 stands with an average PD value of 1.68E-32; third, IB1 with an average PD value of 1.4309E-17. For Islamic banks with the first highest Probability of DefaultIB10, which stands with an average PD value of 0.38005843; second, Bank of IB11 with an average PD value of 0.22451799; third, the IB3 with an average PD value of 0.1639196.

While for the lowest conventional banks, the first Probability of Default is CB1 with an average PD value of $1.7822 \mathrm{E}-05$; second, CB7 with an average PD value of 3.1817E-05; third, CB3 with a PD average of 0.00011895 . For conventional banks, the highest average Probability of Default is CB5 with an average PD value of 0.21773164 ; second, CB6 with an average PD value of 0.17186006 ; third, CB11 with an average PD value of 0.0554459 .

Overall, we can see that the higher the Probability of Default value in a bank, the more likely the bank is at risk of bankruptcy or failure (default risk). Conversely, the lower the Probability of Default value in a bank, the less likely it is to experience the risk of bankruptcy or failure (default risk).

Next is, the T Islamic banks and conventional banks. Based on the data normality test on variables that is not normally distributed, the next test uses the Mann-Whitney test. The Mann-Whitney test was chosen because of the criteria of the test that suit for the difference of two unrelated data, especially when the assumption of testing of the independent sample t-test cannot be met. ${ }^{28}$ The results of the Mann-Whitney difference test on the Probability of Default of Islamic banks and conventional banks are explained in Table 3:

Table 3: Mann-Whitney Test Results

\begin{tabular}{cccc}
\hline Bank type & Obs & Rank Sum & Expected \\
\hline Conventional & 77 & 6638 & 5967.5 \\
Banks & & & \\
Islamic Banks & 77 & 5297 & 5967.5 \\
Combined & 154 & 11935 & 11935 \\
\hline
\end{tabular}

Source: Stata Test Results 14.2 (processed)

28 Suryani \& Hendryadi, Metode Riset Kuantitatif Teori dan Aplikasi pada Penelitian Manajemen dan Ekonomi Islam (Jakarta: Prenadamedia Group, 2015), 298. 
Ho: $\mathrm{pd}($ typeb $\sim \mathrm{k}==$ Conventional Commercial Banks $)=\mathrm{pd}($ typeb $\sim \mathrm{k}==$ Shariah Commercial Banks)

$\mathrm{z}=2.423$

Prob $>|z|=0.0154$

The results of the above test show that the value of prob $>|z|==$ equal to 0.0154 or a probability value of less than 0.05 , which means is rejected and is accepted. So that from the test it can be concluded that there is a significant difference the score of Probability of Default Islamic Banks and Conventional Banks.

Based on the Mann-Whitney U-test in Table 3, indicates that there are significant differences in the Probability of Default values between Islamic Banks and Conventional Banks in Indonesia for the 2011-2017 period with the Merton Model. In addition to knowing whether or not there are differences in Islamic Banks and Conventional Banks, the Mann-Whitney U-test is also used to determine the difference in median of two free groups, namely between Islamic Islamic Banks and Conventional Banks in Indonesia for the period 2011-2017. Although the Mann-Whitney U-test was a non-parametric form of the independent T-test, the Mann-Whitney U-test did not test for differences in the mean of two groups such as the independent T-test, but to test Median differences (scores center) of two groups.

To see the Median difference (middle value) between Islamic Banks and Conventional Banks in Indonesia for the 2011-2017 periods will be explained in Table 4:

Table 4: Median Score (Middle Score) of Probability Default between Islamic Banks and Conventional Banks in Indonesia Period 2011-2017

\begin{tabular}{llllll}
\hline No. & $\begin{array}{c}\text { Name of } \\
\text { Islamic } \\
\text { Banks }\end{array}$ & Median PD & No. & $\begin{array}{c}\text { Name of } \\
\text { Conventional } \\
\text { Banks }\end{array}$ & Median PD \\
\hline 1. IB1 & $6.527 \mathrm{E}-19$ & 1. & CB1 & $1.005 \mathrm{E}-09$ \\
2. & IB2 & 0.0098667 & 2. & CB2 & 0.0071132 \\
3. & IB3 & 0.1583492 & 3. & CB3 & $1.499 \mathrm{E}-07$
\end{tabular}




\begin{tabular}{|c|c|c|c|}
\hline 4. IB4 & $1.69 \mathrm{E}-152$ & 4. CB4 & 0.0093071 \\
\hline 5. IB5 & $7.124 \mathrm{E}-16$ & CB5 & 0.21799 \\
\hline 6. IB6 & $1.948 \mathrm{E}-37$ & 6. CB6 & 0.156747 \\
\hline 7. IB7 & 0.0418169 & 7. $\mathrm{CB} 7$ & $2.439 \mathrm{E}-05$ \\
\hline IB8 & 0.0010003 & CB8 & 0.000312 \\
\hline IB9 & $9.35 \mathrm{E}-13$ & CB9 & 0.005876 \\
\hline 0. IB10 & 0.3943729 & 10. CB10 & 0.0115171 \\
\hline IB11 & 0.3081356 & 11. CB11 & 0.048582 \\
\hline $\begin{array}{l}\text { edian Shariah } \\
\text { mmercial Banks }\end{array}$ & 0.0010003 & $\begin{array}{l}\text { Median Conventional } \\
\text { Commercial Banks }\end{array}$ & 0.0071132 \\
\hline
\end{tabular}

Source: Results of author data processing, 2019

Based on Table 4, it can be seen that based on the Median (middle value) between Islamic banks and conventional banks in Indonesia for the 2011-2017 period, Islamic banks posit a median value (middle value) of 0.0010003 and conventional banks have a median score (middle score) of 0.0071132 . It can be concluded that Islamic banks have a median score (middle score) lower than conventional banks. This means that Islamic banks are banks that are far from the possibility of default risk rather than conventional banks. This is in line with inference of the lower the median value of Probability of Default, the smaller the bank experiences a possible risk of failure (default risk). Hence, the best between Islamic banks and conventional banks in Indonesia (based on the Table 4 of this study) is Islamic banks.

The results of this study are in line with and supported by research by Boumediene, ${ }^{29}$ where the results of the measurement of DD and PD of Islamic banks are lower and better than conventional banks. This is because Islamic banks that were affected by the subprime crisis showed immunity compared to conventional banks, where this crisis also had an impact on the economy. Islamic banks have a low level of credit risk which is also supported by bank operations that use the Musharakah agreement in terms of liability management, where the customer agrees to provide debt to the bank and responsible for obtaining returns. Besides, the agreement in Islamic banks is very strict and the mechanism is really paid attention to as the offering.

Islamic banking operations are very different from conventional banking, where the customer relationship with the bank is consider as a partner that

29 Boumediene, A., 'Is Credit Risk Really Higher in Islamic Banks?' 1-36. 
work together and agree to support investment based on Islamic principles. Meanwhile, the financed investment must avoid activities and produce products that are prohibited in Islamic principles. Among the activities that are prohibited in Islamic principles are those containing theelements of maysīr (speculation), gharar (uncertainty), ribā (interest), and zalim (harming others). So, the selection of business activities managed by Islamic banks is very concerned about and focuses more on the real sector. Most importantly, it must be Shariah-compliant.

The implementation of sharia-compliant in Islamic banking is also supported by Beck et al., ${ }^{30}$ where the main principle in sharia-compliant Islamic banking products is not to violate the rules in the Quran, especially in terms of rib $\bar{a}$ (interest), prioritizing risk-sharing and Islamic contracts. Islamic banks are also prohibited from offering derivative products involving trading in financial products that are considered risky. The relationship between the borrower and depositor is a partnership that prioritizes the mudārabah contract where profit and loss are shared. On the other hand, the murābahah contract has similarities to leasing in conventional banks but is very different where Islamic banking is prohibited from providing money financing and must be involved in the purchase of the goods that being financed. The conventional bank leasing contract also has similarities with the ijärah contract, where the ownership of the goods purchased by the borrower during the financing period belongs to the bank so that the borrower becomes the lessee and is returned when the financing is paid off. In the muräbahah and ijärah contracts, the bank benefits come in the form of profit margins and fees.

The sharia-compliant prohibits the existence of usury (interest) because the service of goods and services at banking has a price so that interest is replaced with fees and contingent payment structures. According to Beck et al, sharia-compliant is also based on the principle of profit-loss sharing of financial statements on the assets and liabilities side that connects all products with the real sector. ${ }^{31}$

The results of this study are in line with research by Kabir et al. ${ }^{32}$ where the results show that the DD of Islamic banks is higher than conventional banks,

30 Beck, T., Demirgüç-Kunt, A. \& Merrouche, O., 'Islamic vs. Conventional Banking: Business Model, Efficiency and Stability,' Policy Research Working Paper, no. WPS 5446 (Washington, D.C.: World Bank Group, 2010), 1-42.

31 Beck, T., Demirgüç-Kunt, A. \& Merrouche, O., 'Islamic vs. Conventional Banking: Business Model, Efficiency and Stability,' 1-42.

32 Kabir, Nurul, 'Comparative Credit Risk in Islamic and Conventional Bank,' $327-$ 353. 
which indicates that conventional banks has a high credit risk than Islamic banks. Islamic banking has shown good financial performance during the global financial crisis, where assets always experience growth before and after the crisis.

The better operation of Islamic banks than conventional banks is also supported by Beck et al. ${ }^{33}$. This is according to the results of their research on the comparison of Islamic banks and conventional banks which shows that based on a sample of banking data from various countries studied, they show that Islamic banking is the most cost-effective compared to conventional banks. However in terms of conventional banks which have a higher market share than Islamic banks, the results are also more cost-effective, and they are more volatile than Islamic banks. When a global financial crisis occurred, Islamic banks showed better performance than conventional banks due to Islamic banks consistency in the capital cushion and high liquidity reserves.

\section{CONCLUSION}

The purpose of this paper is to determine the level of Distance to Default (DD) and Probability Default (PD) in Islamic banks and conventional banks, where DD and PD are measures of risk level in banks using the Merton's Distance to Default model measurement in 11 Islamic banks and conventional banks with the observation period 2011-2017. In general, the results of DD and PD measurements show that Islamic banks have a lower level of credit risk than conventional banks. This is also supported by a different test through the Mann-Whitney U-test on the PD level of Islamic banks and conventional banks which shows a significant difference. The results of the study are in line with the research results of Boumediene ${ }^{34}$ and Kabir et al., ${ }^{35}$ where Islamic banks have higher DD levels than conventional banks, and this shows that the credit risk of Islamic banks is lower than conventional banks.

There are several reasons for the low level of credit risk in Islamic banks. The first is the application of Shariah Compliant ${ }^{36}$ which is based on the operation of Islamic banks in accordance with the Quran, so that Islamic

\footnotetext{
33 Beck, T., Demirgüç-Kunt, A. \& Merrouche, O., 'Islamic vs. Conventional Banking: Business Model, Efficiency and Stability,' 1-42.

34 Boumediene, A., 'Is Credit Risk Really Higher in Islamic Banks?' 1-36.

35 Kabir, Nurul, 'Comparative Credit Risk in Islamic and Conventional Bank,' 327353.

36 Beck, T., Demirgüç-Kunt, A. \& Merrouche, O., 'Islamic vs. Conventional Banking: Business Model, Efficiency and Stability,' 1-42.
} 
bank financial products use Islamic contracts such as murābahah, ijārah, mud̄ārabah, mushārakah, and others. Second, Islamic banks have good financial performance and are considered to be resilient in facing the global financial crisis due to their good management compared to conventional banks such as asset growth, capital cushion, liquidity reserve, do not offer derivative financial products, and always supporting the real sector through financing. Third, the borrower and depositor relationship at Islamic banks is a partnership and responsibility in terms of banking investment and is willing to place funds on the principle of profit-loss sharing. The superiority in the performance and risk management of Islamic banks compared to conventional banks must be further enhanced and in line with the striving efforts to increase market share; since the market share of Islamic banks is still lower than conventional banks.

\section{IMPLICATION}

Comparison of the measurement of the possibility of distance default between Islamic banks and conventional banks has important implications for regulators and supervisors, where the stability of the financial system in the banking sector that runs two banking systems must be the main concern in maintaining economic stability. Measuring the default distance or default risk for both types of banks will provide different regulations and supervision for each type of bank. Measuring the default distance will serve as an early warning system and advice for the banking sector to continue to achieve a condition with a low distance to default, namely by operating by avoiding risk exposure company activities. The operational concept of Islamic banks that uses the concept of profit-loss sharing to avoid the use of interest rates as found in conventional banks shows that, the measurement results of possible default risk show a lower default risk compared to conventional banks.

\section{REFERENCES}

Altman, E., 'Financial Ratios, Discriminant Analysis and the Prediction of Corporate Bankruptcy,' The Journal of Finance, 23. No. 4 (1968): 589609.

Asdriargo, A., Di Asih, I. M. \& Hoyyi, A., 'Pengukuran Risiko Kredit Harga Obligasi dengan Pendekatan Model Struktural Kmv Merton,' Jurnal Gaussian, 1/1 (2012): 11-20.

Ayomi, Sri \& Bambang Hermanto, 'Mengukur Risiko Sistemik dan Keterkaitan Finansial Perbankan di Indonesia,' Buletin Ekonomi Moneter dan Perbankan, vol. 16/2 (2013): 103-125. 
Beck, T., Demirgüç-Kunt, A. \& Merrouche, O., 'Islamic vs. Conventional Banking: Business Model, Efficiency and Stability,' Policy Research Working Paper, no. WPS 5446 (Washington, D.C.: World Bank Group, 2010), 1-42.

Bharath, S. T. \& Shumway, T., 'Forecasting Default with the Merton Distance to Default Model,' The Review of Financial Studies, vol. 21/3 (2008): 1339-1369.

Black, F., Scholes, M., 'The Pricing of Options and Corporate Liabilities,' The Journal of Political Economy (1973): 637-654.

Boumediene, A., 'Is Credit Risk Really Higher in Islamic Banks?' SSRN Electronic Journal, vol. 7/3 (2010): 1-36.

Hadad, D. M., Santoso, W., Besar, S. D., \& Rulina, I., Probabilitas Kegagalan Korporasi dengan Menggunakan Model Merton (Jakarta: Direktorat Penelitian dan Pengaturan Perbankan (BSSK-DPNP) Bank Indonesia, 2004).

Hasan, M. \& Dridi, J., 'The Effects of the Global Crisis on Islamic and Conventional Banks: A Comparative Study,' Journal of International Commerce, Economics and Policy, vol. 2/2 (2011): 163-200.

Jessen, C. \& Lando, D., 'Robustness of Distance-to-Default,' Journal of Banking \& Finance, vol. 50 (2015): 493-505.

Kabir, Nurul, 'Comparative Credit Risk in Islamic and Conventional Bank,' Pacific-Basin Finance Journal, vol. 34 (2015): 327-353.

Karim, Adiwarman, Bank Islam Analisis Fiqih dan Keuangan (Jakarta: PT. Raja Grafindo Persada, 2014).

Koutsomanoli-Filippaki, A. \& Mamatzakis, E., 'Performance and Merton-type Default Risk of Listed Banks in the EU: A Panel VAR Approach,' Journal of Banking \& Finance, vol. 33/11 (2009): 2050-2061.

Larsson, Maria \& Birger Nilsson, 'Predicting the Default Probability of Companies in USA and EU During the Financial Crisis: A Study Based on the KMVTм Model,' (Master Dissertation, Lund University, Swedia, 2010).

Machmud, Amir \& Rukmana, Bank Syariah Teori, Kebijakan, dan Studi Empiris di Indonesia (Jakarta: PT. Gelora Aksara Pratama, 2010). 
Masood, O., Tafri, F. H., Rahman, R. A. \& Omar, N., 'Empirical Evidence on the Risk Management Tools Practised in Islamic and Conventional Banks,' Qualitative Research in Financial Markets, vol. 3 (2011): 86104.

Merton, Robert C., On the Pricing of Corporate Debt: The Risk Structure on Interest Rates (New York: Wiley and American Finance Association, 1974).

Otoritas Jasa Keuangan, Statistik Perbankan Indonesia (Jakarta: Otoritas Jasa Keuangan, 2017).

Saeed, M., \& Izzeldin, M., 'Examining the Relationship between Default Risk and Efficiency in Islamic and Conventional Banks,' Journal of Economic Behavior \& Organization, vol. 132 (2016): 127-154.

Suryani \& Hendryadi, Metode Riset Kuantitatif Teori dan Aplikasi pada Penelitian Manajemen dan Ekonomi Islam (Jakarta: Prenadamedia Group, 2015).

Wibowo, Buddi, 'Metode Pengukuran Probabilitas Kebangkrutan Bank dan Analisis Hubungannya dengan Diversifikasi Sumber Pendapatan: Kasus Perbankan Indonesia,' Matrik: Jurnal Manajemen Strategi Bisnis dan Kewirausahaan, vol. 11/1 (2017): 52-66.

Wiranatakusuma, D. B. \& Duasa, J., 'Building An Early Warning Towards the Resilience of Islamic Banking in Indonesia,' Al-Iqtishad: Jurnal Ilmu Ekonomi Syariah, vol. 9/1 (2017): 13-32. 


\section{Appendix 1}

Table 1: Probability of Default Shariah Commercial Banks 2011-2017 Period

\begin{tabular}{|c|c|c|c|c|c|}
\hline \multicolumn{3}{|c|}{ IB1 } & \multicolumn{3}{|c|}{ IB5 } \\
\hline Year & DD & $\mathrm{PD}$ & Year & DD & $\mathrm{PD}$ \\
\hline 2011 & 9.847874 & $3.50047 \mathrm{E}-23$ & 2011 & 9.543079 & $6.93268 \mathrm{E}-22$ \\
\hline 2012 & 8.280628 & $6.12637 \mathrm{E}-17$ & 2012 & 8.368092 & $2.92793 \mathrm{E}-17$ \\
\hline 2013 & 8.350063 & $3.41134 \mathrm{E}-17$ & 2013 & 8.136266 & $2.03828 \mathrm{E}-16$ \\
\hline 2014 & 9.222004 & $1.45799 \mathrm{E}-20$ & 2014 & 7.820375 & $2.6333 \mathrm{E}-15$ \\
\hline 2015 & 9.116 & $3.8974 \mathrm{E}-20$ & 2015 & 7.9833 & $7.12361 \mathrm{E}-16$ \\
\hline 2016 & 8.597326 & $4.07976 \mathrm{E}-18$ & 2016 & 7.004074 & $1.24312 \mathrm{E}-12$ \\
\hline 2017 & 8.805275 & $6.5266 \mathrm{E}-19$ & 2017 & 7.308599 & $1.34971 \mathrm{E}-13$ \\
\hline \multicolumn{2}{|c|}{ Mean PD } & $1.4309 \mathrm{E}-17$ & \multicolumn{2}{|c|}{ Mean PD } & $1.9738 \mathrm{E}-13$ \\
\hline \multicolumn{3}{|c|}{ IB2 } & \multicolumn{3}{|c|}{ IB6 } \\
\hline Year & $\mathrm{DD}$ & PD & Year & $\mathrm{DD}$ & PD \\
\hline 2011 & 2.807444 & 0.002496818 & 2011 & 12.73262 & $1.94776 \mathrm{E}-37$ \\
\hline 2012 & 2.215875 & 0.013350029 & 2012 & 11.71423 & $5.38858 \mathrm{E}-32$ \\
\hline 2013 & 1.889292 & 0.029426324 & 2013 & 11.70028 & $6.35187 \mathrm{E}-32$ \\
\hline 2014 & 2.45967 & 0.006953246 & 2014 & 13.56242 & 3.34449E-42 \\
\hline 2015 & 2.783673 & 0.002687361 & 2015 & 13.01923 & 4.75654E-39 \\
\hline 2016 & 2.331377 & 0.009866739 & 2016 & 12.74939 & $1.57101 \mathrm{E}-37$ \\
\hline 2017 & 1.98991 & 0.023300437 & 2017 & 12.22375 & $1.16065 \mathrm{E}-34$ \\
\hline \multicolumn{2}{|c|}{ Mean PD } & 0.01258299 & \multicolumn{2}{|c|}{ Mean PD } & $1.6789 \mathrm{E}-32$ \\
\hline \multicolumn{3}{|c|}{ IB3 } & \multicolumn{3}{|c|}{ IB7 } \\
\hline Year & DD & PD & Year & $\mathrm{DD}$ & PD \\
\hline 2011 & 1.289427 & 0.098624776 & 2011 & 1.72998 & 0.041816923 \\
\hline 2012 & 1.001266 & 0.158349173 & 2012 & 1.478393 & 0.069651371 \\
\hline 2013 & 1.046998 & 0.147550186 & 2013 & 1.583207 & 0.056687191 \\
\hline 2014 & 0.890522 & 0.186592869 & 2014 & 1.974043 & 0.024188452 \\
\hline 2015 & 1.220953 & 0.111051874 & 2015 & 2.083111 & 0.018620546 \\
\hline 2016 & 0.808082 & 0.209521588 & 2016 & 1.649016 & 0.049572168 \\
\hline 2017 & 0.720051 & 0.235746725 & 2017 & 1.898605 & 0.02880823 \\
\hline
\end{tabular}




\begin{tabular}{cccccc}
\hline \multicolumn{2}{c}{ Mean PD } & 0.1639196 & \multicolumn{2}{c}{ Mean PD } & 0.04133498 \\
\multicolumn{7}{c}{ Source: Results of author data processing, 2019} \\
\multicolumn{7}{c}{ IB4 } \\
\hline \multicolumn{7}{c}{ Year } & DD & \multicolumn{1}{c}{ PD } & Year & DD & \multicolumn{1}{c}{ PD } \\
\hline 2011 & 27.50095 & $8.5519 \mathrm{E}-167$ & 2011 & 4.032095 & $2.7641 \mathrm{E}-05$ \\
2012 & 23.34323 & $8.0729 \mathrm{E}-121$ & 2012 & 3.253093 & 0.000570781 \\
2013 & 20.17576 & $7.99362 \mathrm{E}-91$ & 2013 & 3.081501 & 0.001029799 \\
2014 & 27.3396 & $7.1784 \mathrm{E}-165$ & 2014 & 3.062514 & 0.001097432 \\
2015 & 28.66596 & $5.071 \mathrm{E}-181$ & 2015 & 3.090141 & 0.001000307 \\
2016 & 26.27847 & $1.69 \mathrm{E}-152$ & 2016 & 3.01519 & 0.001284094 \\
2017 & 24.2438 & $3.8437 \mathrm{E}-130$ & 2017 & 3.155506 & 0.000801101 \\
\hline Mean PD & $1.1419 \mathrm{E}-91$ & \multicolumn{3}{c}{ Mean PD } & 0.00083016 \\
\hline
\end{tabular}

\begin{tabular}{|c|c|c|c|c|c|}
\hline \multicolumn{3}{|c|}{ IB9 } & \multicolumn{3}{|c|}{ IB10 } \\
\hline Year & $\mathrm{DD}$ & PD & Year & DD & PD \\
\hline 2011 & 4.760512 & $9.65511 \mathrm{E}-07$ & 2011 & 1.082752 & 0.139459318 \\
\hline 2012 & 5.709335 & $5.67091 \mathrm{E}-09$ & 2012 & 0.404424 & 0.342950599 \\
\hline 2013 & 6.67866 & $1.20568 \mathrm{E}-11$ & 2013 & 0.191515 & 0.424060878 \\
\hline 2014 & 7.198502 & $3.04389 \mathrm{E}-13$ & 2014 & 0.301137 & 0.381655171 \\
\hline 2015 & 7.57601 & $1.78172 \mathrm{E}-14$ & 2015 & 0.26794 & 0.394372884 \\
\hline 2016 & 9.350624 & $4.3566 \mathrm{E}-21$ & 2016 & 0.148671 & 0.440906454 \\
\hline 2017 & 7.043844 & $9.35041 \mathrm{E}-13$ & 2017 & -0.09289 & 0.5370037 \\
\hline \multicolumn{2}{|c|}{ Mean PD } & $1.3874 \mathrm{E}-07$ & \multicolumn{2}{|c|}{ Mean PD } & 0.38005843 \\
\hline
\end{tabular}




\begin{tabular}{cll}
\hline \multicolumn{3}{c}{ IB11 } \\
\hline Year & \multicolumn{1}{c}{ DD } & \multicolumn{1}{c}{ PD } \\
\hline 2011 & 7.385 & $7.62269 \mathrm{E}-14$ \\
2012 & 5.660016 & $7.56792 \mathrm{E}-09$ \\
2013 & 0.48738 & 0.312994538 \\
2014 & 0.536597 & 0.295773011 \\
2015 & 0.488427 & 0.312623748 \\
2016 & 0.406741 & 0.342099043 \\
2017 & 0.501142 & 0.308135588 \\
\hline \multicolumn{2}{l}{ Mean PD } & 0.22451799 \\
\hline
\end{tabular}

Source: Results of author data processing, 2019

Table 2: Probability of Default Conventional Commercial Bank 2011-2017 Period

\begin{tabular}{clclcc}
\hline \multicolumn{2}{c}{ CB1 } & \multicolumn{3}{c}{ CB5 } \\
\hline \multicolumn{1}{c}{ Year } & \multicolumn{1}{c}{ DD } & PD & Year & DD & PD \\
\hline 2011 & 3.665381 & 0.000123485 & 2011 & 0.692495 & 0.244313131 \\
2012 & 4.705454 & $1.26651 \mathrm{E}-06$ & 2012 & 0.705888 & 0.240128941 \\
2013 & 6.173562 & $3.33842 \mathrm{E}-10$ & 2013 & 0.740858 & 0.229389631 \\
2014 & 5.997073 & $1.00453 \mathrm{E}-09$ & 2014 & 0.793254 & 0.213814837 \\
2015 & 5.76612 & $4.05586 \mathrm{E}-09$ & 2015 & 0.841732 & 0.199969044 \\
2016 & 6.993413 & $1.34139 \mathrm{E}-12$ & 2016 & 0.779 & 0.217989977 \\
2017 & 6.619107 & $1.80687 \mathrm{E}-11$ & 2017 & 0.921036 & 0.178515893 \\
\hline \multicolumn{3}{l}{ Mean PD } & $\mathbf{1 . 7 8 2 2 E - 0 5}$ & \multicolumn{4}{c}{ Mean PD } & 0.21773164 \\
\hline
\end{tabular}




\begin{tabular}{cccccc}
\hline \multicolumn{2}{c}{ CB2 } & \multicolumn{3}{c}{ CB6 } \\
\hline Year & DD & PD & Year & DD & PD \\
\hline 2011 & 2.431436 & 0.007519558 & 2011 & 0.623478 & 0.26648531 \\
2012 & 2.451493 & 0.007113247 & 2012 & 0.853726 & 0.196628407 \\
2013 & 2.444927 & 0.007244069 & 2013 & 1.165287 & 0.121951478 \\
2014 & 2.437241 & 0.007399905 & 2014 & 1.12381 & 0.130546805 \\
2015 & 2.586774 & 0.004843953 & 2015 & 1.008727 & 0.156552888 \\
2016 & 2.643178 & 0.004106598 & 2016 & 0.938053 & 0.174108486 \\
2017 & 2.731866 & 0.003148841 & 2017 & 1.007918 & 0.156747034 \\
\hline \multicolumn{3}{l}{ Mean PD } & 0.00591088 & \multicolumn{3}{c}{ Mean PD } & 0.17186006 \\
\hline
\end{tabular}

\begin{tabular}{cccccc}
\hline \multicolumn{3}{c}{ CB3 } & \multicolumn{3}{c}{ CB7 } \\
\hline Year & \multicolumn{1}{c}{ DD } & PD & Year & DD & PD \\
\hline 2011 & 3.308033 & 0.000469768 & 2011 & 3.837445 & $6.21604 \mathrm{E}-05$ \\
2012 & 3.380126 & 0.000362263 & 2012 & 3.879894 & $5.22509 \mathrm{E}-05$ \\
2013 & 5.161287 & $1.22629 \mathrm{E}-07$ & 2013 & 4.061434 & $2.43861 \mathrm{E}-05$ \\
2014 & 5.180228 & $1.10807 \mathrm{E}-07$ & 2014 & 4.640453 & $1.73823 \mathrm{E}-06$ \\
2015 & 5.275922 & $6.60452 \mathrm{E}-08$ & 2015 & 4.771176 & $9.15767 \mathrm{E}-07$ \\
2016 & 5.116428 & $1.55688 \mathrm{E}-07$ & 2016 & 4.082415 & $2.22851 \mathrm{E}-05$ \\
2017 & 5.12362 & $1.49862 \mathrm{E}-07$ & 2017 & 3.850306 & $5.89852 \mathrm{E}-05$ \\
Mean PD & $\mathbf{0 . 0 0 0 1 1 8 9 5}$ & Mean PD & $3.1817 \mathrm{E}-05$ \\
\multicolumn{5}{l}{} \\
\hline
\end{tabular}


Probability of Default Measurement Models of Merton on Shariah Banks and Conventional Banks in Indonesia for 2011-2017 Period

\begin{tabular}{|c|c|c|c|c|c|}
\hline \multicolumn{3}{|c|}{ CB4 } & \multicolumn{3}{|c|}{ CB8 } \\
\hline Year & DD & PD & Year & $\mathrm{DD}$ & PD \\
\hline 2011 & 1.767645 & 0.038560126 & 2011 & 2.85754 & 0.002134694 \\
\hline 2012 & 1.976587 & 0.02404417 & 2012 & 3.035854 & 0.001199279 \\
\hline 2013 & 2.158159 & 0.015457744 & 2013 & 3.509506 & 0.00022447 \\
\hline 2014 & 2.353167 & 0.009307134 & 2014 & 3.450537 & 0.000279736 \\
\hline 2015 & 3.26704 & 0.000543392 & 2015 & 3.541978 & 0.000198569 \\
\hline 2016 & 2.995455 & 0.001370179 & 2016 & 3.420926 & 0.000312041 \\
\hline 2017 & 2.700611 & 0.003460616 & 2017 & 3.382474 & 0.00035918 \\
\hline \multicolumn{2}{|c|}{ Mean PD } & 0.01324905 & \multicolumn{2}{|c|}{ Mean PD } & 0.00067257 \\
\hline \multicolumn{3}{|c|}{ CB9 } & \multicolumn{3}{|c|}{ CB10 } \\
\hline Year & DD & PD & Year & DD & PD \\
\hline 2011 & 2.206943 & 0.013659011 & 2011 & 2.272867 & 0.011517089 \\
\hline 2012 & 2.334108 & 0.009795026 & 2012 & 2.224078 & 0.013071592 \\
\hline 2013 & 2.542352 & 0.005505463 & 2013 & 2.761964 & 0.002872738 \\
\hline 2014 & 2.519507 & 0.005875965 & 2014 & 2.733894 & 0.003129506 \\
\hline 2015 & 2.412797 & 0.007915308 & 2015 & 2.278191 & 0.011357607 \\
\hline 2016 & 3.128932 & 0.000877216 & 2016 & 1.901985 & 0.028586544 \\
\hline 2017 & 2.995896 & 0.001368199 & 2017 & 1.753562 & 0.039752774 \\
\hline \multicolumn{2}{|c|}{ Mean PD } & 0.00642803 & \multicolumn{2}{|c|}{ Mean PD } & 0.01575541 \\
\hline
\end{tabular}


Jurnal Syariah, Jil. 29, Bil. 1 (2021) 65-90

\begin{tabular}{ccc}
\hline \multicolumn{2}{c}{ CB11 } \\
\hline Year & DD & \multicolumn{1}{c}{ PD } \\
\hline 2011 & 1.430782 & 0.076246311 \\
2012 & 1.362825 & 0.086468791 \\
2013 & 1.616374 & 0.053006788 \\
2014 & 1.797841 & 0.036101132 \\
2015 & 1.759075 & 0.039282394 \\
2016 & 1.660232 & 0.048433943 \\
2017 & 1.658761 & 0.048581958 \\
\hline Mean PD & 0.0554459 \\
\hline
\end{tabular}

Source: Results of author data processing, 2019 